\title{
FOTODEGRADASI SIANIDA DALAM LIMBAH CAIR TAPIOKA
}

\author{
Kapti Riyani*, Tien Setyaningtyas \\ Staf pengajar Prodi Kimia Jurusan MIPA FST UNSOED \\ *e-mail : kapti.riyani@gmail.com
}

\begin{abstract}
ABSTRAK
Sianida banyak terdapat pada limbah cair tapioka. Sianida dapat didegradasi menggunakan fotokatalis $\mathrm{TiO}_{2}$ dengan aktivasi sinar UV, sinar UV dapat berasal dari lampu UV dan sinar matahari. Tujuan dari penelitian ini adalah mendegradasi sianida menggunakan fotokatalis $\mathrm{TiO}_{2}$ menggunakan sumber sinar lampu UV dan sinar matahari.

Fotokatalis $\mathrm{TiO}_{2}$ yang digunakan dalam penelitian ini dibuat lapis tipis pada plat kaca dengan ukuran $7 \times 10 \mathrm{~cm}^{2}$. Variasi sumber sinar yaitu lampu UV dan sinar matahari dipelajari pada $\mathrm{pH} 9$.

Hasil penelitian menunjukkan bahwa penurunan kadar sianida menggunakan sumber sinar lampu UV dengan lama penyinaran 8 jam sebesar 90,69\%, sedangkan penurunan kadar sianida menggunakan sumber sinar matahari dengan lama penyinaran 8 jam sebesar $98,74 \%$.
\end{abstract}

Kata kunci : Fotokatalis, $\mathrm{TiO}_{2}$, sianida, degradasi

\section{PHOTODEGRADATION OF CYANIDE IN TAPIOCA WASTEWATERS}

\begin{abstract}
Cyanide is widely available in tapioca wastewater. Cyanide can be degraded by used $\mathrm{TiO}_{2}$ photocatalysts with activated by UV light, UV light can be derived from UV lamp and sunlight. The aim of this research is to degrade cyanide using $\mathrm{TiO}_{2}$ photocatalysts using UV lamp and sun light as a source.

$\mathrm{TiO}_{2}$ photocatalyst used in this study was made thin layers on glass plates with a size of $7 \times 10 \mathrm{~cm}^{2}$. Variation of the light source is a UV light and sunlight studied at pH 9.

The results suggest that decreased levels of cyanide using UV light source with a long 8 hours of irradiation at $90.69 \%$, while decreasing levels of cyanide using a source with a long exposure to sunlight for 8 hours of $98.74 \%$.

Key word : Photocatalyst, $\mathrm{TiO}_{2}$, cyanide, degradation

\section{PENDAHULUAN}

Sianida adalah racun yang sangat mematikan dan digunakan sejak ribuan tahun yang lalu. Efek dari sianida ini sangat cepat dan dapat mengakibatkan kematian dalam jangka waktu beberapa menit (Wahyudhy, 2006). Sianida dalam tubuh manusia dapat menghambat

pernafasan jaringan. Kadar sianida yang tinggi dalam darah dapat menyebabkan efek seperti jari tangan dan kaki lemah, susah berjalan dan pandangan buram (Setiadji, 1990). Sianida biasanya ditemukan tergabung dalam bahan kimia lain membentuk suatu senyawa sianida. Sebagai contoh senyawa sianida yang sederhana adalah hidrogen sianida.
\end{abstract}


Hidrogen sianida disebut juga formonitril, sedang dalam bentuk cairan disebut asam hidrosianik (Wahyudhy, 2006).

Sianida dapat ditemukan pada rokok, asap kendaraan bermotor, dan makanan seperti bayam, bambu, kacang, tepung tapioka dan singkong (Nio, 1989). Kadar sianida rata-rata dalam singkong manis di bawah $50 \mathrm{mg} \cdot \mathrm{kg}^{-1}$ berat asal, sedangkan singkong pahit di atas 50 mg. $\mathrm{kg}^{-1}$ berat asal. Menurut FAO, singkong atau umbi-umbian dengan kadar HCN dibawah 50 mg.kg-1 masih aman untuk dikonsumsi manusia (Winarno, 1995). Menurut Suprapti (2005) menyatakan bahwa di dalam daging umbi dan kulit singkong terdapat racun yang dikenal dengan nama hydrocyan atau HCN. Racun tersebut tidak terdapat dalam keadaan berdiri sendiri, melainkan terikat dalam suatu rangkaian yang dikenal dengan nama glukosida sianogenik, yang terdiri dari glukosa, aseton dan HCN. Cara terbaik mengurangi atau menghilangkan racun tersebut adalah dengan membuat tepung tapioka atau kanji dari singkong tersebut. Apabila singkong tersebut diparut, maka sel-selnya menjadi pecah sehingga glukosida dan $\mathrm{HCN}$ akan terpisah. Oleh karena pekerjaan membuat tepung itu membutuhkan banyak air dan air tersebut harus sering diperbaharui, maka glukosida maupun sianida itu akhirnya turut terbuang sebagai limbah.

Industri tapioka merupakan salah satu industri yang berkembang pesat di Indonesia. Industri ini menghasilkan limbah padat dan cair. Limbah padat industri tapioka dapat dimanfaatkan untuk berbagai keperluan, seperti; limbah padat yang berasal dari proses pengupasan ketela pohon dari kulitnya yaitu berupa kotoran dan kulit serta pada waktu pemrosesan yang berupa ampas dimana sebagian besar berupa serat dan pati dapat dimanfaatkan sebagai makanan ternak, pupuk, bahan campuran saus, dan obat nyamuk bakar. Sedangkan Limbah cair yang dihasilkan dari proses pembuatan, baik dari pencucian bahan baku sampai pada proses pemisahan pati dari airnya dapat dimanfaatkan untuk minuman nata de cassava. Limbah industri tapioka yang mempunyai kandungan bahan organik yang tinggi (termasuk didalamnya yaitu sianida), apabila tidak diolah dengan baik dan benar dapat menimbulkan berbagai masalah bagi kesehatan, misalnya: gatalgatal, timbul bau yang tidak sedap, air limbah bila masuk ke dalam tambak akan merusak tambak sehingga ikan mati, estetika sungai berubah dan lain-lain (Wahyuadhy, 1996).

Fotokatalisis merupakan kombinasi proses dari fotokimia dan katalisis, dimana diperlukan sinar UV dan katalis (semikonduktor) untuk melangsungkan suatu transformasi kimia. Proses fotoreduksi dan fotooksidasi dimulai pada saat fotokatalis mengadsorbsi energi foton dengan energi yang sama atau lebih besar dari energi celah semikonduktor $\left(\mathrm{TiO}_{2}\right.$ mempunyai energi celah sebesar $3.2 \mathrm{eV}$ ) sehingga elektron akan tereksitasi dari pita valensi ke pita konduksi. Pasangan elektron $\left(\mathrm{e}^{-}\right)$dan hole $\left(\mathrm{h}^{+}\right)$yang terbentuk dapat berekombinasi dan melepaskan panas atau menyebabkan reaksi oksidasi dan reduksi dengan transfer muatan ke spesies yang teradsorbsi pada permukaan semikonduktor. Hole $\left(\mathrm{h}^{+}\right)$yang dihasilkan $\mathrm{TiO}_{2}$ merupakan oksidator kuat yang akan mengoksidasi spesi kimia lainnya yang mempunyai potensial oksidasi $+1.0 \mathrm{~V}$ sampai $+3.5 \mathrm{~V}$ (relatif terhadap elektroda hydrogen-Nerst) (Hoffmann, 1995), termasuk air dan/atau gugus hidroksil yang akan menghasilkan radikal hidroksil. Radikal hidroksil ini pada $\mathrm{pH}=1$ mempunyai potensial sebesar $2.8 \mathrm{~V}$, dan kebanyakan zat organik mempunyai potensial redoks yang lebih kecil dari potensial tersebut, sehingga kebanyakan zat organik dapat dioksidasi menjadi $\mathrm{CO}_{2}$ (Gunlazuardi, 2001). Sementara elektron pada pita konduksi merupakan reduktor kuat yang akan mereduksi spesi kimia lainnya yang mempunyai potensial reduksi $+0.5 \mathrm{~V}$ sampai $-1.5 \mathrm{~V}$ (relatif 
terhadap elektroda hydrogen-Nerst) (Hoffmann, 1995). Energi foton yang digunakan untuk eksitasi elektron dari fotokatalis $\mathrm{TiO}_{2}$ adalah sinar UV dan sinar tampak. (Yan-fen, 2007 ; Sopyan, 1998 dan Linsebigler, 1995). Disamping $\mathrm{TiO}_{2}$, semikonduktor lain seperti $\mathrm{ZnO}$ dan $\mathrm{WO}_{3}$ mempunyai karakter yang sebanding dengan $\mathrm{TiO}_{2}$ dalam hal energi band gap dan potensial redoksnya. Namun $\mathrm{TiO}_{2}$ paling banyak digunakan sebagai fotokatalis karena paling stabil (tahan terhadap korosi) dan harganya relatif murah (Gunlazuardi, 2001).

$\begin{array}{cr}\text { Fotokatalisis } & \text { heterogen } \\ \text { menggunakan titanium dioksida }\end{array}$
merupakan metode yang efisien untuk mendegradasi secara lengkap senyawa organik dalam fase cair dan gas. Pencemar yang mengandung karbon, hidrogen, nitrogen, sulfur dan atom halogen akan terdegradasi menjadi $\mathrm{CO}_{2}, \mathrm{H}_{2} \mathrm{O}$, anion $\mathrm{NO}_{3}{ }^{-}, \mathrm{SO}_{4}{ }^{2-}$, dan halida (Hoffmann, 1995). Metode fotokatalitik $\mathrm{TiO}_{2}$ berhasil digunakan dalam beberapa aplikasi komersial, termasuk pemurnian air, unit pembersih udara, pelapis antimikroba dan kaca self-cleaning. Jumlah paten yang berkaitan dengan degradasi senyawaan organik yang berbahaya menggunakan teknik fotokatalitik terus meningkat. Namun, kebanyakan dari mereka masih menggunakan sumber sinar dari lampu UV karena energi celah pita dari $\mathrm{TiO}_{2}$ cukup besar $(3,2 \mathrm{eV})$ sehingga bila menggunakan sinar matahari kurang efisien karena hanya menggunakan $\pm 5 \%$ dari spektrum sinar matahari (fraksi UV cahaya matahari) (Anpo, 2000).

Fotodegradasi sianida $\left(\mathrm{CN}^{-}\right)$telah dilakukan dengan menggunakan $\mathrm{TiO}_{2}$, $\mathrm{CdS}, \mathrm{ZnO}, \mathrm{V}_{2} \mathrm{O}_{5}$, dan $\mathrm{Fe}_{2} \mathrm{O}_{3}$ sebagai katalis. Akan tetapi, hanya $\mathrm{TiO}_{2}$ dan $\mathrm{ZnO}$ yang memberikan hasil memuaskan (Dabrowski, 2005). Menurut Pollema (1992), sianida akan teroksidasi menjadi sianat kemudian menjadi nitrat menggunakan $\mathrm{TiO}_{2}$ Degussa P-25.
Mekanisme dasar proses fotokatalisis adalah terbentuknya pasangan elektron-hole pada permukaan katalis semikonduktor ketika diinduksi oleh enegi foton yang sesuai (Gunlazuardi, 2001). $\mathrm{TiO}_{2}$ dapat mengkatalisis reaksi reduksi dan oksidasi. Reaksi oksidasi dapat terjadi karena lubang positif yang terbentuk selama aktivasi fotokatalis akan mengoksidasi ion hidroksi atau air pada permukaan katalis menghasilkan radikal hidroksil HO• Radikal ini akan mengoksidasi senyawaan organik pada limbah cair tekstil. Mekanisme reaksi digambarkan oleh Sonawane et. al. (2006), tahapannya sebagai berikut:

$$
\begin{aligned}
& \mathrm{TiO}_{2}+\mathrm{hv} \rightarrow \mathrm{TiO}_{2}\left(\mathrm{e}^{-}+\mathrm{h}^{+}\right) \\
& \mathrm{h}^{+}+\mathrm{OH}_{\mathrm{ad}}^{-} \rightarrow \cdot \mathrm{OH}_{\mathrm{ad}} \\
& \mathrm{h}^{+}+\mathrm{H}_{2} \mathrm{O}_{\mathrm{ad}} \rightarrow \cdot \mathrm{OH}_{\mathrm{ad}}+\mathrm{H}^{+}
\end{aligned}
$$

radikal hidroksil $\bullet \mathrm{OH}$ yang dihasilkan memiliki peranan penting dalam mengoksidasi senyawaan organik. Semakin tinggi pembentukan hidroksil radikal maka akan semakin besar pula kemampuan fotokatalis untuk mengoksidasi senyawaan organik. Proses fotokatalisis menggunakan katalis semikonduktor secara efektif mampu mendegradasi berbagai jenis polutan organik, baik dalam fasa gas maupun cair. Proses fotooksidasi dapat mendegradasi senyawa-senyawa organik menjadi produk anorganik yang aman bagi lingkungan, yaitu $\mathrm{CO}_{2}$ dan $\mathrm{H}_{2} \mathrm{O}$ (Slamet, 2006). Dalam penelitian ini, digunakan fotokatalis $\mathrm{TiO}_{2}$ karena $\mathrm{TiO}_{2}$ mempunyai aktivitas fotokatalis yang tinggi, mudah didapat, serta mempunyai kestabilan kimia dan ketahanan fotokorosi yang baik (Slamet, 2006).

Tujuan dari penelitian ini adalah mempelajari pengaruh sumber sinar yaitu lampu UV dan sinar matahari dalam mendegradasi sianida pada limbah cair tapioka pada $\mathrm{pH} 9$ dimana merupakan $\mathrm{pH}$ 
optimum dari penurunan kadar sianida pada limbah cair tapioka menggunakan $\mathrm{TiO}_{2}$ (Riyani, 2010).

\section{METODE PENELITIAN}

\section{Alat dan Bahan.}

Alat-alat yang digunakan dalam penelitian ini adalah Magnetic Stirrer (REXIM RSH-1DM), indikator universal, Spektrofotometer UV-Vis (Shimadzu 1800), Hair dryer (Phillips), Beker gelas, labu ukur, Lampu UV (Himawari) 10 watt.

Bahan-bahan yang digunakan dalam penelitian ini adalah $\mathrm{TiO}_{2}$ (Merch), aquadest (Bratachem), $\mathrm{KOH}$ (Merch), $\mathrm{KCN}$ (Merch), etanol (Merch), $\mathrm{CuSO}_{4}$ (Merch), $\mathrm{HCl}$ (Merch) dan $\mathrm{NaOH}$ (Merch).

\section{Prosedur Penelitian}

\section{Penentuan Sianida.}

Sebanyak $25 \mathrm{~mL}$ larutan standar sianida dimasukkan ke dalam 6 buah labu takar $50 \mathrm{~mL}$ dengan konsentrasi masingmasing 0, 1, 2, 3, 4 dan 5 ppm. Kemudian masing-masing ditambah $10 \mathrm{~mL} \mathrm{KOH}$ $0,05 \%$ dan $10 \mathrm{~mL}$ larutan pp-CuSO4, lalu diencerkan sampai $50 \mathrm{~mL}$ dan dibiarkan sampai terbentuk warna merah muda. Setelah itu, diukur absorbansinya dengan spektrofotometer sinar tampak pada panjang gelombang maksimum. Percobaan yang sama dilakukan untuk sampel limbah cair tapioka.

\section{Pembuatan Lapis Tipis $\mathrm{TiO}_{2}$.}

Plat kaca berukuran $3 \mathrm{~cm} \mathrm{x} 7 \mathrm{~cm}$ dimasukkan ke dalam suspensi $\mathrm{TiO}_{2} \quad 15 \%$ $(\mathrm{b} / \mathrm{v})$, selanjutnya plat kaca dikeringkan dengan hair dryer. Plat kaca selanjutnya dipanaskan pada suhu $120{ }^{\circ} \mathrm{C}$ selama 1 jam.

\footnotetext{
Fotodegradasi Sianida Menggunakan $\mathrm{TiO}_{2} /$ lampu UV.
}

Sebanyak 1 gelas beaker $500 \mathrm{ml}$ yang berisi $250 \mathrm{ml}$ limbah tapioka, yang dikondisikan pada $\mathrm{pH} 9$ dimana merupakan $\mathrm{pH}$ optimum untuk fotodegradasi sianida (Riyani, 2010) dengan cara menambahkan $\mathrm{HCl} 1 \mathrm{~N}$ atau $\mathrm{NaOH} 1 \mathrm{~N}$ ke dalam sampel air limbah. Sampel yang telah dikondisikan pada $\mathrm{pH} 9$ kemudian dilakukan analisis kadar sianida awal. Lapis tipis $\mathrm{TiO}_{2}$ dimasukkan pada sampel air limbah dan ditempatkan dalam reaktor tertutup sambil disinari lampu ultraviolet selama 10 jam dan dianalisis kadar sianidanya setelah penambahan fotokatalis $\mathrm{TiO}_{2}$.

\section{Fotodegradasi Sianida Menggunakan $\mathrm{TiO}_{2} /$ sinar matahari.}

Sampel air limbah sebanyak 250 $\mathrm{mL}$ dimasukkan ke dalam gelas beker 500 $\mathrm{mL}$ kemudian dikondisikan pada $\mathrm{pH} 9$. Kemudian lapis tipis $\mathrm{TiO}_{2}$ dimasukkan ke dalam sampel air limbah yang telah dikondisikan pada $\mathrm{pH}$ optimum dan ditempatkan pada daerah dimana terkena sinar matahari secara langsung. Penentuan kadar sianida dilakukan setelah penyinaran selama $0,1,2,4,6,8$ jam.

\section{HASIL DAN PEMBAHASAN}

\section{Fotodegradasi Sianida Menggunakan} $\mathrm{TiO}_{2} /$ lampu UV.

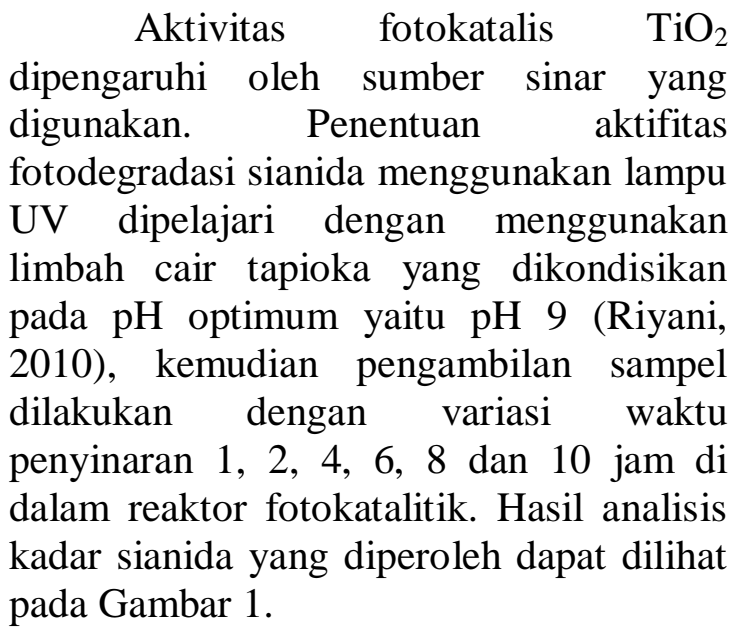

Aktivitas fotokatalis $\mathrm{TiO}_{2}$ dipengaruhi oleh sumber sinar yang digunakan. Penentuan aktifitas fotodegradasi sianida menggunakan lampu UV dipelajari dengan menggunakan limbah cair tapioka yang dikondisikan pada pH optimum yaitu pH 9 (Riyani, 2010), kemudian pengambilan sampel dilakukan dengan variasi waktu penyinaran 1, 2, 4, 6, 8 dan 10 jam di dalam reaktor fotokatalitik. Hasil analisis pada Gambar 1. 
Tabel 1. Pengaruh waktu penyinaran lampu UV sebagai sumber sinar terhadap aktifitas fotokatalis $\mathrm{TiO}_{2}$

\begin{tabular}{|l|c|c|c|c|c|c|c|}
\hline Waktu (jam) & 0 & 1 & 2 & 4 & 6 & 8 & 10 \\
\hline $\begin{array}{l}\text { Penurunan Kadar } \\
\text { Sianida (\%) }\end{array}$ & 0 & 49,66 & 65,85 & 69,79 & 71,38 & 90,69 & 93,79 \\
\hline
\end{tabular}

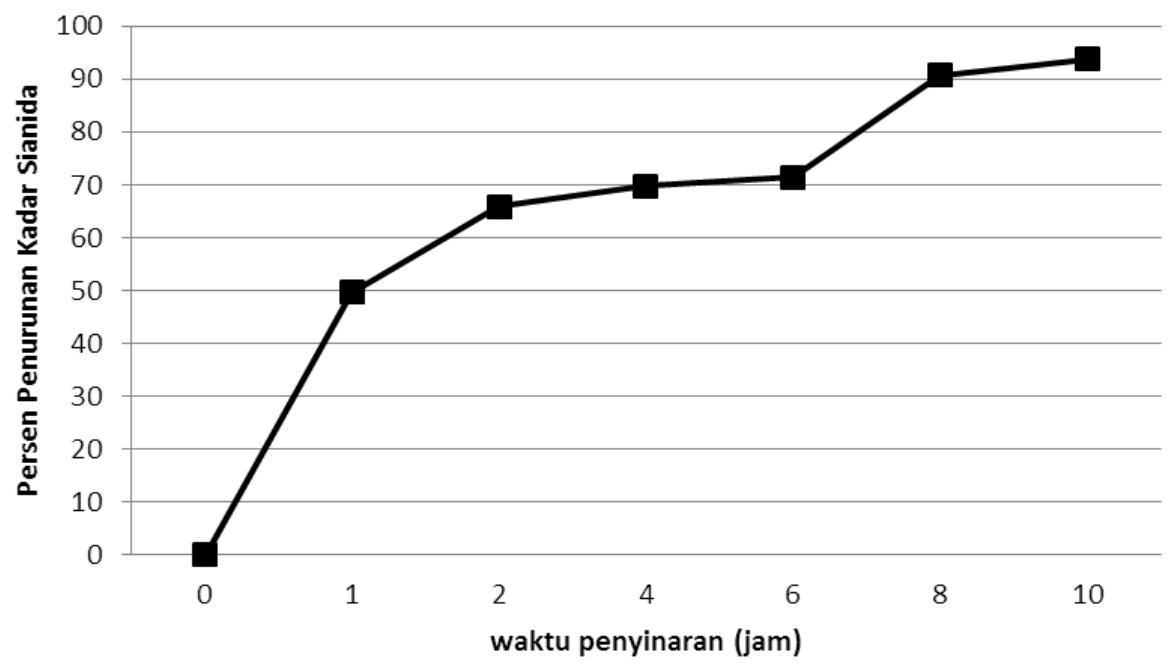

Gambar 1. Pengaruh waktu penyinaran lampu UV sebagai sumber sinar terhadap aktifitas fotokatalis $\mathrm{TiO}_{2}$

Dengan adanya pencahayaan ultra violet $\left(1<405 \mathrm{~nm}\right.$ ) pada permukaan $\mathrm{TiO}_{2}$ maka $\mathrm{TiO}_{2}$ akan mempunyai kemampuan menginisiasi reaksi kimiawi. Kebanyakan senyawa organik, dalam media air dapat dioksidasi oleh $\mathrm{TiO}_{2}$ menjadi karbon dioksida dan air, sehingga proses fotokatalisis oleh $\quad \mathrm{TiO}_{2}$ dapat membersihkan air dari pencemar organik, sedangkan senyawa-senyawa anorganik seperti sianida dan nitrit yang beracun dapat diubah menjadi senyawa lain yang relatif tidak beracun.

Penyinaran permukaan $\mathrm{TiO}_{2}$ yang bersifat semikonduktor akan menghasilkan pasangan elektron dan hole positif. Hole positif pada permukaan $\mathrm{TiO}_{2}$ tersebut merupakan spesi oksidator kuat karena akan mengoksidasi spesi kimia lainnya yang mempunyai potensial redoks lebih kecil, termasuk dalam hal ini molekul air dan gugus hidroksil yang akan menghasilkan radikal hidroksil yang mampu mengoksidasi senyawa organik dalam larutan.

Mekanisme fotokatalisis semikonduktor $\mathrm{TiO}_{2}$ dengan adanya sinar UV dapat dijelaskan sebagai berikut. Apabila $\mathrm{TiO}_{2}$ dikenai cahaya dengan energi foton $(h v)$ yang sama atau lebih besar daripada energi celah pita maka sebuah elektron akan dipromosikan dari pita valensi ke pita konduksi yang akan mengakibatkan lubang (hole) pada pita valensi, hal ini mengakibatkan pita valensi akan memiliki muatan positif $\left(h^{+}\right)$dan pita konduksi akan bermuatan negatif karena mendapatkan tambahan elektron $\left(e^{-}\right)$. Reaksinya menurut El-amin (2007) adalah sebagai berikut :

$h v$

$\mathrm{TiO}_{2} \quad \rightarrow \quad h_{v b}^{+}+e_{c b}$

Lubang positif pada pita valensi $h_{v b}{ }^{+}$dan elektron pada pita konduksi $e_{c b}{ }^{-}$ dapat berekombinasi. Jika $h_{v b}{ }^{+}$bereaksi 
dengan suatu donor elektron maka akan terjadi reaksi oksidasi, sedangkan apabila $e_{c b}{ }^{-}$bereaksi dengan suatu akseptor elektron maka akan terjadi reaksi reduksi. Selanjutnya hole $\left({h_{v b}}^{+}\right)$akan bereaksi dengan hidroksida logam yaitu $\mathrm{TiO}_{2}$ membentuk radikal hidroksida logam, radikal hidroksida logam ini merupakan oksidator kuat yang akan mengoksidasi sianida. Elektron yang berada pada permukaan semikonduktor akan terjebak dalam hidroksida logam dan akan bereaksi dengan penangkap elektron yang ada dalam larutan, misalnya $\mathrm{H}_{2} \mathrm{O}$ atau $\mathrm{O}_{2}$, membentuk radikal hidroksil $(\cdot \mathrm{OH})$ maupun superoksida $\left(\cdot \mathrm{O}_{2}\right)$ yang akan mengoksidasi sianida dalam larutan. Radikal-radikal ini akan terus-menerus terbentuk selama $\mathrm{TiO}_{2}$ disinari dengan sinar UV dan akan menyerang sianida sehingga sianida tersebut akan terdegradasi.

Kadar sianida dianalisis pada waktu $0,1,2,4,6,8$ dan 10 jam setelah penyinaran menggunakan lampu UV dengan katalis $\mathrm{TiO}_{2}$ lapis tipis. Konsentrasi sianida pada limbah cair industri tapioka yang digunakan sebesar 4,29 mg/L. Hasil dari pengaruh lampu UV sebagai suber sinar terhadap aktifitas fotokatalis $\mathrm{TiO}_{2}$ dalam mendegradasi sianida dalam limbah cair tapioka dapat dilihat pada Gambar 1.

Berdasarkan Gambar 1 terlihat bahwa persentase penurunan kadar sianida dalam limbah cair tapioka paling besar terjadi pada waktu penyinaran 10 jam dengan persentase penurunan sebesar 93,79\%, konsentrasi sianida setelah 10 jam penyinaran adalah $0,27 \mathrm{mg} / \mathrm{L}$. Hal tersebut menunjukkan bahwa persentase penurunan kadar sianida sebanding dengan waktu penyinaran yang berarti semakin lama waktu penyinaran, semakin banyak energi foton $(h v)$ yang diserap $\mathrm{TiO}_{2}$ sehingga semakin banyak elektron pada pita valensi yang tereksitasi pada pita konduksi. Kondisi ini menyebabkan $\mathrm{h}^{+}$ atau lubang positif yang terbentuk juga semakin banyak. Lubang positif tersebut akan bereaksi dengan $\mathrm{H}_{2} \mathrm{O}$ atau ion hidroksil membentuk radikal $\cdot \mathrm{OH}$ yang kemudian digunakan untuk menguraikan senyawa organik termasuk sianida dalam limbah cair tapioka (Hoffman, 1995).

Mekanisme reaksi fotokatalitik $\mathrm{TiO}_{2}$ dalam pembentukan radikal hidroksil secara umum dapat dijelaskan pada persamaan reaksi berikut (Fujishima, 1999) :

$$
\begin{aligned}
& \mathrm{TiO}_{2}+h v \rightarrow h^{+}+e^{-} \\
& \mathrm{TiO}_{2}\left(e^{-}\right)+\mathrm{O}_{2} \rightarrow \mathrm{TiO}_{2}+\bullet \mathrm{O}_{2} \\
& \bullet \mathrm{O}_{2}+\mathrm{H}^{+} \rightarrow \mathrm{HO}_{2} \bullet \\
& \bullet \mathrm{O}_{2}+\mathrm{HO}_{2} \bullet \rightarrow \mathrm{O}_{2}+\cdot \mathrm{OH}+\mathrm{H}_{2} \mathrm{O}_{2} \\
& 2 \mathrm{HO}_{2} \bullet \rightarrow \mathrm{O}_{2}+\mathrm{H}_{2} \mathrm{O}_{2} \\
& \mathrm{TiO}_{2}\left(e^{-}\right)+\mathrm{H}_{2} \mathrm{O}_{2} \rightarrow \mathrm{TiO}_{2}+\cdot \mathrm{OH}+{ }^{-} \mathrm{OH} \\
& \mathrm{TiO}_{2}\left(h^{+}\right)+{ }^{-} \mathrm{OH} \rightarrow \cdot \mathrm{OH}
\end{aligned}
$$

Menurut Pollema (1992), sianida akan teroksidasi menjadi sianat kemudian menjadi nitrat dengan mekanisme reaksi sebagai berikut (Kim, 2003) :

$$
\begin{aligned}
& \mathrm{OH}^{-}+\mathrm{h}^{+} \rightarrow \mathrm{OH}^{\cdot} \\
& \mathrm{OH}^{-}+\mathrm{Ti}-\mathrm{O}^{-} \rightarrow \mathrm{OH}^{-}+\mathrm{Ti}^{-} \mathrm{O}^{-} \\
& \mathrm{CN}^{-}+\mathrm{h}^{+} \rightarrow \mathrm{CN}^{\cdot} \\
& \mathrm{CN}^{-}+\mathrm{Ti}-\mathrm{O}^{-} \rightarrow \mathrm{CN}^{-}+\mathrm{Ti}^{-} \mathrm{O}^{-} \\
& 2 \mathrm{CN} \cdot \rightarrow(\mathrm{CN})_{2} \\
& (\mathrm{CN})_{2}+\mathrm{OH}^{-} \rightarrow \mathrm{OCN}^{-}+\mathrm{CN}^{-}+\mathrm{H}_{2} \mathrm{O} \\
& \mathrm{OH}^{\cdot}+\mathrm{CN}^{-} \rightarrow \mathrm{HOCN} \cdot \\
& \mathrm{HOCN}^{-} \rightarrow \quad \mathrm{C}^{\cdot} \mathrm{ONH}_{2} \\
& 2 \mathrm{C} \cdot \mathrm{ONH}_{2} \rightarrow \mathrm{HCONH}_{2}+\mathrm{HOCN} \\
& \mathrm{OCN}^{-}+8 \mathrm{OH}^{-}+8 \mathrm{H}^{+} \rightarrow \mathrm{NO}_{3}^{-}+\mathrm{CO}_{2}+ \\
& 4 \mathrm{H}_{2} \mathrm{O} \\
& \mathrm{OCN}^{-}+2 \mathrm{H}_{2} \mathrm{O} \rightarrow \mathrm{NH}_{4}{ }^{+}+\mathrm{CO}_{3}{ }^{2-}
\end{aligned}
$$


Fotodegradasi Sianida dalam Limbah Cair... (Kapti Riyani dan Tien Setyaningtyas)

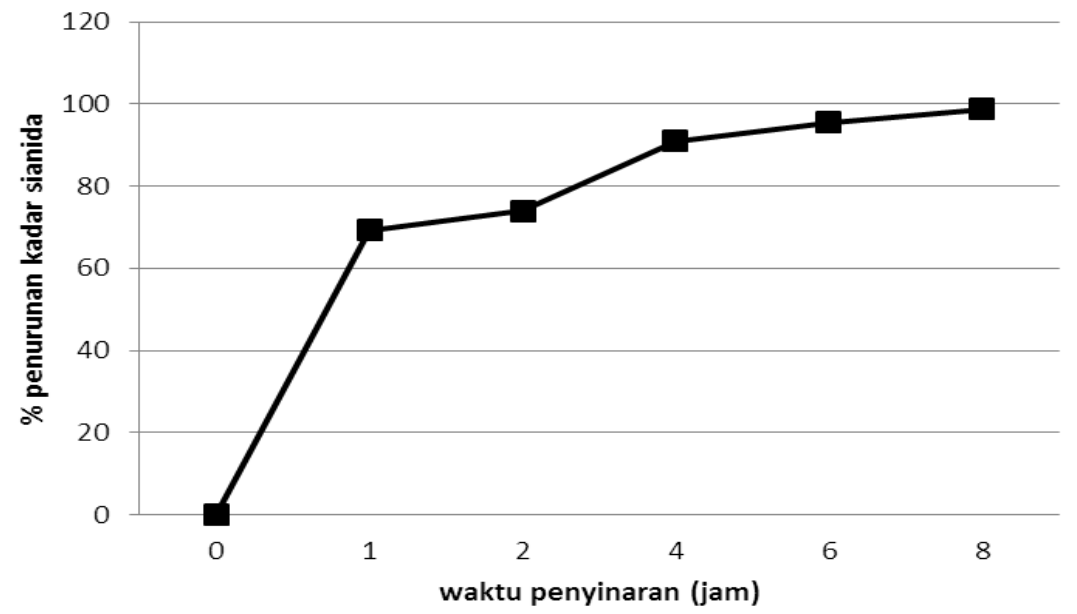

Gambar 2. Pengaruh Waktu Penyinaran Sinar Matahari sebagai Sumber Sinar terhadap Aktifitas Fotodegradasi Sianida.

Tabel 2. Pengaruh Waktu Penyinaran Sinar Matahari sebagai Sumber Sinar terhadap Aktifitas Fotodegradasi Sianida.

\begin{tabular}{|l|c|c|c|c|c|c|}
\hline Waktu (jam) & 0 & 1 & 2 & 4 & 6 & 8 \\
\hline Penurunan Kadar Sianida (\%) & 0 & 69,23 & 79,99 & 90,91 & 95,46 & 98,74 \\
\hline
\end{tabular}

\section{Pengaruh Sinar Matahari Untuk Fotodegradasi Sianida Pada pH Optimum.}

Salah satu faktor yang mempengaruhi aktivitas fotokatalis $\mathrm{TiO}_{2}$ adalah penggunaan sumber sinar. Kadar sianida sebelum dan sesudah penambahan lapis tipis $\mathrm{TiO}_{2}$ dengan penyinaran menggunakan sinar matahari selama 8 jam dianalisis. Hasil dari pengaruh penggunaan sinar matahari terhadap aktifitas fotokatalis $\mathrm{TiO}_{2}$ dalam menurunkan kadar sianida dalam limbah cair tapioka dapat dilihat pada Gambar 2.

Sinar matahari dapat digunakan sebagai sumber sinar UV untuk fotodegradasi sianida pada limbah cair tapioka, hal ini dikarenakan sinar matahari mengandung sinar UV kurang lebih 5\%. Besarnya penurunan kadar sianida pada kondisi penyinaran dengan sinar matahari selama 8 jam adalah $98,75 \%$, sedangkan besarnya penurunan kadar sianida pada kondisi penyinaran dengan lampu UV selama 8 jam adalah 90,67 \%. Hal ini menunjukkan bahwa aktifitas fotodegradasi sianida lebih baik bila menggunakan sinar matahari dibanding menggunakan sumber sinar lampu UV. Hal tersebut menunjukkan bahwa penggunaan sinar matahari untuk proses fotodegradasi sianida pada limbah tapioka lebih baik bila dibandingkan pada penggunaan lampu UV, sehingga proses pengolahan limbah menjadi lebih efisien bila menggunakan sinar matahari karena tidak membutuhkan lampu UV dan sumber listrik lagi.

Pada limbah cair tapioka selain terdapat sianida juga terdapat senyawa organik lain seperti karbohidrat, protein, lemak serta senyawa anorganik. Adanya senyawa organik kompleks dan senyawa anorganik dalam limbah cair tapioka dan adanya sinar tampak selain sinar UV yang terdapat pada sinar matahari maka dimungkinkan mekanisme fotodegradasi sianida pada limbah cair tapioka 
menggunakan mekanisme sinar tampak dengan bantuan sensitizer senyawa organik kompleks dan senyawa anorganik dan mekanisme menggunakan sinar UV, hal ini mengakibatkan aktifitas fotokatalis pada penggunaan sinar matahari lebih tinggi bila dibandingkan pada penggunaan sinar yang berasal dari lampu UV.

\section{KESIMPULAN}

Berdasarkan hasil penelitian ini, maka dapat disimpulkan bahwa :

1. Fotokatalis $\mathrm{TiO}_{2}$ dapat menurunkan kadar sianida dalam limbah cair tapioka

2. Sinar matahari lebih baik bila digunakan sebagai sumber sinar untuk fotodegradasi sianida pada limbah cair tapioka. Besarnya persentase penurunan kadar sianida dengan menggunakan sumber sinar matahari selama 8 jam adalah 98,7386\%, sedangkan persentase penurunan kadar sianida dengan menggunakan sumber sinar lampu UV selama 8 jam adalah $90,67 \%$.

\section{SARAN}

1. Perlu diteliti penggunaan reaktor alir agar proses pengolahan limbah menjadi lebih efisien.

2. Perlu dikembangkan fotokatalis yang lebih aktif terhadap sinar tampak yang banyak terdapat pada sinar matahari sehingga proses fotodegradasi limbah organik lebih efisien.

\section{DAFTAR PUSTAKA}

Anpo, M., (2000), Utilization of $\mathrm{TiO} 2$ photocatalysts in green chemistry, Pure Appl. Chem., 72, 1265-1270.

Dabrowski, B., Jan Hupka, Monica, Z., Jan D. Miller, 2005, Laboratory and Pilot Scale Photodegadation of
Cyanide-Containing Wastewaters, Journal of Physicochemical Problems of Mineral Processing, 39 (2005), 229-248

El-Amin, A.A., Rashed, M.N., 2007., Photocatalytic Degradation of Methyl Orange in Aqueous Under Different Solar Irradiation Sources, Journal of Physical Sciences, Vol 2 (3), p 073-081

Fujishima., Akira., kazuhita Hashimoto., Toshiya Watanabe., 1999., $\mathrm{TiO}_{2}$ Photocatalysis: Fundamentals and Applications., Bkc, Inc., Tokyo

Gunlazuardi, J., 2001., Fotokatalisis Pada Permukaan $\mathrm{TiO}_{2} \quad$ : Aspek fundamental dan aplikasinya. Seminar Nasional Kimia Fisika II, Kimia, F MIPA, Universitas Indonesia

Hoffmann, M.R.; Martin, S.T.; Choi, W.; Bahnemann, D., 1995., Environmental Applications Of Semiconductor Photocatalysis, Chem. Rev., 95, 69-96.

Kim, J.H., Ho-In Lee, 2003, Photocatalytic Oxidation of Aqueous Cyanide Using $\mathrm{TiO} 2$ and Surface-Modified TiO2, Journal of Photochemistry and Photobiology, A : Chemistry, 66, 367-374.

Linsebigler, A.L., Lu, G., Yates, J.T., 1995., Photocatalysis on $\mathrm{TiO}_{2}$ Surface: Principles, Mechanism, and Selected Result., Chem. Rev., 735-758

Nio, Kam Oey, 1989, Zat-zat Toksik yang Secara Alamiah Ada pada Bahan Makanan Nabati Cermin Dunia Kedokteran No.58, 24-28

Pollema, C. H., Hendrix, J. L., Milosavljevic, E. B., Solujic, L., Nelson, J. H., 1992, Heterogeneus Photocatalytic Oxidation of Cyanide to Nitrat at Titania Particle, Journal of Photochemistry 
and Photobiology, A : Chemistry, 66, 235-244.

Peral, J., Munoz, J., Domenech, X., 1990, Photosensitized Cyanide Oxidation Over Titanium dioxide, Journal of Photochemistry and Photobiology, $A$ : Chemistry, 55, 251-257.

Riyani, Kapti dan Tien Setyaningtyas., 2010., Penurunan Kadar Sianida Dalam Limbah Cair Tapioka Menggunakan Fotokatalis $\mathrm{TiO}_{2}$, Molekul, 5 / 1 / 50-55

Suprapti, Lies., 2005., Tepung Tapioka, Penerbit Kanisius, Yogyakarta, ISBN 979-21-0854-8

Setiadji, B., Tranggono, Suparno, Sardjono, dan Ibnu Ghalib G, 1990, Kajian Kimiawi Pangan II, Cetakan Pertama, Tiara Wacana PUA Pangan dan Gizi UGM, Yogyakarta, Hal 273-283.

Slamet, S. Bismo, Rita A., dan Zulaina, S., 2006, Penyisihan Fenol dengan Kombinasi Proses Absorpsi dan Fotokatalisis Menggunakan Karbon Aktif dan TiO2, Jurnal Teknologi, Fakultas Teknik, Depok, UI. Slamet, Meta, E,. Dan S. Bismo, 2008, Modifikasi Zeolit Alam Lampung dengan Fotokatalis TiO2 Melalui Metode Sol Gel dan Aplikasinya untuk Penyisihan Fenol, Jurnal Teknologi, Fakultas Teknik, Depok, UI.
Sonawane, R.S., dan M.K. Dongare., 2006, Sol-gel Synthesis of $\mathrm{Au} / \mathrm{TiO}_{2}$ Thin Films for Photocatalytic Degradation of Phenol in Sunlight, Journal of Molecular Catalysis A: Chemical, 243, 68-76

Sopyan, I., 1998., Fotokatalitik Semikonduktor-Dasar Teori dan Penerapan., Majalah BPPT, No LXXXVII

Wahyuadhy, S., 1996, Teknologi Pengendalian Dampak Lingkungan Industri Penyamakan Kulit (online), Disampaikan dalam Raker Pengendalian Pencemaran Air Akibat Limbah Usaha Kecil, Http://www.menlh.go.id/usahakecil/. Diakses tanggal 4 Maret 2011.

Wahyudhy, U., 2006, Keracunan Sianida (on-line).

http://klikharry.wordpress.com/200

6/12/14/keracunan-sianida/, Diakses tanggal 4 Maret 2011.

Winarno, F.G., 1995, Kimia Pangan dan Gizi, PT, Gramedia Pustaka Utama, Jakarta, Hal 228-230.

Yan-fen FANG, HUANG Ying-ping, LIU De-fu, HUANG yang, GUO Wei, DAVID Johnson., 2007, Photocatalytic degradation of the dye sulforhodamine-B: A comparative study of different light sources., Journal of Environmental Sciences, 19, 97-102 